\title{
International undergraduate business students’ perceptions of employability
}

\author{
Eszter Kiss $^{1}$, Michelle Barker ${ }^{2}$,Parlo Singh ${ }^{3}$ \\ ${ }^{1}$ College of Business, Law and Governance, James Cook University, Australia, ${ }^{2}$ Department \\ of Business, Strategy \& Innovation, Griffith University, Australia, ${ }^{3}$ School of Education and \\ Professional Studies, Griffith University, Australia.
}

\begin{abstract}
Graduate employability is a highly contested topic by education providers, employers and governments. The responsibility of universities to enhance students' employability through work-integrated learning (WIL) opportunities is also debated.

This study explored international students' understanding of employability skills and their self-perceptions of their employability at an Australian university. It also investiaged students' perception of the universities' role in enhancing employability. A qualitative approach informed by Social Cognitive Career Theory (Lent, Brown \& Hackett, 1994), used multiple focus groups comprising 18 international undergraduate students from Brazil, China, Colombia, India, Papua New Guinea, South Korea in their final semester at an urban Australian university.
\end{abstract}

The key findings are: (1) Participants were unable to differentiate between employability skills, personality traits and job-specific skills; (2) The importance of social skills and networking were recognised by Chinese respondents, in particular; (3) The perceived level of work-readiness was higher among respondents who had previous work experience; (4) The inclusion of more practical WIL components in the degree program calls for curriculum review; (5) Creating opportunities for students to apply their knowledge and skills in professional contexts is highly desirable. The findings highlight curriculum considerations needed in the development of high-quality WIL experiences that will enable students to apply the knowledge and skills learnt in the classroom, thus enhancing their self-efficacy about their employability.

Keywords: employability skills, work-readiness, international students, Social Cognitive Career Theory. 


\section{Introduction}

Influenced by the forces of globalisation, the higher education sector has undergone rapid changes over the last two decades. During this time, employers have expressed concerns that graduates lack transferable skills (Industry in Education, 2001; Paisey \& Paisey, 2010), and universities have responded by seeking ways to improve graduates' skills. Work Integrated Learning (WIL) opportunities and government initiatives aimed at enhancing job-specific and personal transferable skills are seen as important strategies. WIL is a form of learning whereby study is alternated with industry work placements; this provides students with opportunities to integrate the theories they learn with the practices of the workplace (Bowen \& Drysdale, 2017; Eames \& Cates, 2011; Nica \& Popescu, 2010).

The study aims to explore international students' perceptions of employability, their understanding of employability skills, and the perceived roles of universities in preparing students for employment. Employability is defined by Nilsson (2010, p. 547) as the ability to "successfully manage a job" and "control one’s individual career path, thus creating opportunities for mobility and self-efficacy". As individuals are developing their employability skills, they are preparing for working life (Nilsson, 2010). By the term employability skills, this study refers to the skills demanded by employers for successful employment, notably: communication skills, teamwork skills, problem solving skills, planning and organising skills, self- management skills and digital literacy, ability to work with protocols, decision making skills, creative thinking, being flexible, and the ability to work with diverse points of views (Archer \& Davison, 2008; Department of Education and Training, 2009; Department of Industry, Innovation, Climate Change, Science, Research and Tertiary Education and Department of Education, Employment and Workplace Relations, 2013; Shah \& Nair, 2011).

\section{Background}

Through the process of internationalisation, careers are becoming boundaryless (Arthur \& Rousseau, 1996). Hartwig et al., (2017) identify the components of internationalisation of higher education as: enrolment of international students, development of international campuses, exchange programs for students and staff, internationalisation of the curriculum, global research projects and global competition for talent. Another powerful force is multiculturalism, a postmodern construct that promotes cultural diversity and social equality within and across nations (Foster, 2013).

The Australian Government Department of Education and Training (2016) set out a plan to develop the country's role in education while responding to global trends. The 'National Strategy for International Education 2025' is built on three pillars aiming to: (i) strengthen education, student experience and quality assurance; (ii) to establish transformative 
partnerships within and outside of the country; and (iii) to compete globally to grow international education. This report places emphasis on work-integrated opportunities on top of the acquisition of industry-specific skills as employability is a key driver for students undertaking a degree course. The pressure on institutions providing business education to provide work-ready graduates is increasing. Universities are introducing WIL opportunities into the curriculum to enhance graduate employability while engaging students in a range of activities that integrate learning and practice (Bennett \& Ferns, 2017).

This study gave voice to the students and explored their perceptions about employability. In doing so, the Social Cognitive Career Theory (SCCT) was applied as the theoretical framework. SCCT (Lent et al., 1994) is based on Bandura's (1977) social cognitive theory, which has long captured the interest of researchers in the area of education and career development. SCCT was developed with the aim of summarising and organising existing career-related findings on self-efficacy, while incorporating other social cognitive concepts. SCCT aimed to explain the factors that shape educational and vocational interests.

\section{Methods}

This study used qualitative methods - specifically, focus group interviews. The research approach followed Marton's (1975) phenomenographic research that aims to identify ways in which different people experience, perceive, and understand a phenomenon.

\subsection{Participants}

Participants were in their final year level undertaking their Bachelor of Business degree at an urban Australian university. Data were collected in two study periods with the participation of 18 students in total. These students were studying in majors of accounting, international business, management and tourism and hospitality. The country of origin of participants were: one student from Brazil, eight from China, one from Colombia, five from India, two from Papua New Guinea, and one from South Korea.

\section{Findings}

\subsection{Understanding employability skills}

Participants' understanding of employability skills were varied. These are summarised in Table 1. The responses are mostly concerned with employers' expectations or applicants' skills, experience, ability and personality. 
Table 1. Interpretation of employability skills

Participants' definition
Business/employer/managers’ expectation or skills they
want from employees
Skills you pre-achieved
Experience relevant to the job/real workplace
Ability and skills to put into work
Ability that can help you to get a job
Replace someone who's already working
How the skills are used
Personality

\subsection{Ranking employability skills}

The three most important employability skills mentioned by participants were communication skills, team work skills and problem solving skills - regarding the domain of their desired career. The confusion about the difference between employability skills, jobspecific technical skills and personality traits was an interesting finding. Even though, participants were able to define employability, they could not seem to list specific employability skills, and certainly could not differentiate between employability skills, technical skills and personality traits.

\subsection{Enhancing participants' employability}

Participant's attempt to enhance their employability took several forms such as volunteering, paid part-time work, unpaid work experience, industry mentorship, networking, military service and learning a language other than English.

\subsection{Perceived employability}

On a scale of zero (not at all confident about employability) to five (absolutely confident), four students indicated they were 'absolutely ready' for work. One student reported level four on the scale, while another student chose one on the scale. The rest of the participants (12) scored around the middle. Participants who indicated level five had all gained work experience. Where participants indicated a lower score, they lacked practical experience in the field of their studies. The rest of the participants reported different issues resulting in a self-score of three. These were visa constraints, family issues, the desire to pursue further studies and lack of work experience. 


\subsection{Career goals}

The individual career goals of participants were listed as follows. Four participants wished to become the owner of their own business in the fields of finance, taxation, interior design and hospitality. The other career domains were banking, taxation and accounting, marketing, hotels, airport, tourism, construction industry, transport and logistics or human resources. Participants were also asked to share their desired career goals for the future. They had a plan of progression to start working for an organisation of their interest, then move on to a management position in five years' time, and finally to become a general manager or owner of business in ten years' time.

\subsection{Universities' role in students' employment}

Participants' perceptions of universities' role in enhancing employability were diverse. In general, they reported they gained firm foundations in theoretical knowledge and critical and analytical skills. They also highlighted team work, case studies, real life examples, guest speakers and the work of career services as important components. They wish to engagage, however, in more internships (during and at the end of the degree) and professional activities to put theory in practice. Participans also expressed the need for more social events, whereby they can increase the size of their network. Curiously, while they wish to obtain volunteering opportunities, participants have done nothing to engage in such activities.

\section{Discussion and conclusion}

There were five major themes that emerged from this study. First, participants were unable to differentiate between employability skills, technical skills and employability skills. Even though both skills and attributes are important for employers when it comes to selecting and promoting their employees, there seemed to be some confusion about the meaning of the terms. It can be speculated after the review of the literature, that a possible cause of confusion might stem from the terms employability skills and work-readiness skills being used interchangeably. Work-readiness skills tend to include attributes such as honesty, strong work ethic, creativity, flexibility as well as skills, for instance, interpersonal skills, team work skills or technology skills (Ahmad \& Pesch, 2017). Employability skills, on the other hand, are more focused on competencies as outlined by the Core Skills for Work Framework (Department of Industry, Innovation, Climate Change, Science, Research and Tertiary Education and Department of Education, Employment and Workplace Relations, 2013).

Second, social skills were reported to be important especially for participants from China. Respondents explained that their career progression is not only dependent on who they know, but also on their parents' professional network. Networking and getting to know fellow 
students were reported to be beneficial activities. However, these respondents also expressed their uncertainty in networking in a Western context.

Third, the role of previous work experience was an important contributor to students' perceived level of employability. Those participants who ranked themselves higher compared to the others had reported previous work experience and they also had employment secured after graduation. The other respondents who ranked their confidence in employability lower indicated diverse reasons such as the dominance of theoretical knowledge over practical application, the desire to pursue further education and the lack of work experience.

Fourth, the desire to include more practical components of the degree was expressed. Participants expressed their need for putting theory into practice and including more practical components in the degree program. As only two respondents engaged in employment close to their career desires, it is safe to state that respondents did not engage in extra-curricular activities to develop their professional identity in their dream career. Respondents in this study were more likely to wait for the University to do something to further their career goals, instead of taking the initiative, themselves. Ironically, self-initiative is one of the employability skills listed by the Department of Industry, Innovation, Climate Change, Science, Research and Tertiary Education and Department of Education, Employment and Workplace Relations (2013).

Fifth, the application of the subject matter was a recurring theme. In the order of frequency, the following desires were expressed: internships and projects with industry involvement; on-course internships project work; on-site visits; observations and guest-speakers from different industries; job-specific extra-curricular workshops; social activities; and the opportunities for improving presentation skills.

The practical contributions of the study can be conceptualised in the components and supporting factors of employability in the university context. The components of employability are employability skills, industry-specific technical skills, and academic foundational knowledge. The supporting factors include social activities, engagement with industry professionals, and academic support provided by the higher education institution. These findings call for curriculum considerations and a close collaboration amongst stakeholders who are focused on graduates' employability. Bringing more industry professionals into the classroom, taking more students out on field trips, workplace observations, work-shadowing, or career events require educational institutions to work closely with industry professionals. Conversely, students need to take and/or create the opportunity to put everything they studied into practice. Enhancing their employability starts with students' willingness to do so. These issues would make for relevant, fruitful research projects for future studies. 


\section{Acknowledgments}

I acknowledge with thanks, Professor Parlo Singh, Griffith Unviersity School of Education and Professional Studies, for her guidance on this project.

\section{References}

Ahmad, S. \& Pesch, M. (2017). Essential work skills and readiness: Perceptions of employers. MBA students and undergraduates. Academy of Educational Leadership Journal, 21(1), B1-10. Retrieved from http://go.galegroup.com.libraryproxy.griffith.edu.au/ps/i.do?p=AONE\&u=griffith\&id= GALE|A539696988\&v=2.1\&it=r\&sid=summon

Archer, W. \& Davison. J. (2008). Graduate Employability: What do employers think and want? The Council for Industry and Higher Education. Retrieved from http://aces.shu.ac.uk/support/staff/employability/resources/CIHE\%20\%200802Grademployability.pdf

Arthur, M. B. \& Rousseau, D. M. (1996). The boundaryless career: A new employment principle for new organizational era. New York, US: Oxford University Press.

Bandura, A. (1977). Self-Efficacy: Toward a unifying theory of bahavioral change. PsychologicalReview, 84(2), 191-215. Retrieved from https://www.uky.edu/ eushe2/Bandura/Bandura1977PR.pdf

Bennett, D. \& Ferns, S. (2017). Functional and cognitive aspects of employability: implications for international students. In G. Barton, \& K. Hartwig (Eds.), Professional learning in the work place for international students: Exploring theory and practice (pp. 203-222). Cham, Switzerland: Springer.

Bowen, T. \& Drysdale, M. T. B. (2017). Work-integrated learning in the 21st century: Global perspectives on the future. Bingley, UK: Emerald Publishing

Department of Education and Training (2009). Employability skills and workplace culture in Australia. A guide for migrants to Western Australia planning to enter the workforce. Retrieved

from http://vetinfonet.dtwd.wa.gov.au/Resourcesandlinks/Documents/6.1.1_Employability_g uide_Skills_work_place_culture-guide_for_migrants.pdf

Department of Education and Training (2016). National strategy for international education 2025. Australian Government. Retrieved from https://nsie.education.gov.au/

Department of Industry, Innovation, Climate Change, Science, Research and Tertiary Education and Department of Education, Employment and Workplace Relations (2013). Core skills for work developmental framework. Retrieved from https://www.education.gov.au/core-skills-work-developmental-framework

Eames, C., \& Cates, C. (2011). Theories of learning in cooperative education. In R. Coll, K.E. Zegwaard, \& M.A. Lowell (Eds.), International Handbook for cooperative and work-integrated education (pp. 41-52). Boston: World Association for Cooperative Education, Inc. 
Foster, C. (2013). Genuine multiculturalism: The tragedy and comedy of diversity. Montreal, CA: McGill-Queen's University Press.

Hartwig, K., Barton, G., Bennett, D., Cain, D., Campbell, M., Ferns, S., Jones, L., Joseph, D., Kavanagh, M., Kelly, A., Larkin, I., O’Connor, E., Podorova, A., Tangen, D., \& Westerveld, M. (2017). What does internationalisation or interculturalisation look like in the future in the higher education sector? In G. Barton, \& K. Hartwig (Eds.), Professional learning in the work place for international students: Exploring theory and practice (pp. 313-320). Cham, Switzerland: Springer.

Industry in Education, (2001). Graduates employability skills. Radlett: Industry in Education Trust. Innovation and Science Australia (2017). Australia 2030: Prosperity through innovation. Canberra, ACT: Australian Government.

Lent, R. W., Brown, S. D. \& Hackett, G. (1994). Toward a unifying social cognitive theory of career and academic interest, choice, and performance. Journal of Vocational Behavior, 45(1), 79-122. doi: https://doi.org/10.1006/jvbe.1994.1027

Nica, E. \& Popescu, G. (2010). Work-integrated learning an anti-crisis policy to empower economic growth. Bulletin of the Transilvania University of Brasov. Economic Sciences. Series V, 3(52), 413-418. Retrieved from https://search-proquestcom.libraryproxy.griffith.edu.au/docview/872843866?pqorigsite=summon\&https://search.proquest.com/central

Nilsson, S. (2010). Enhancing individual employability: The perspective of engineering graduates. Education + Training, 52(6/7), 540-51. doi: 10.1108/00400911011068487

Paisey, C. \& Paisey, N. J. (2010). Developing skills via work placements in accounting: Student and employer views. Accounting Forum, 34(2), 89-108. doi: 10.1016/j.accfor.2009.06.001

Shah, M. \& Nair, C. S. (2011). Employer satisfaction of university graduates: Key capabilities in early career graduates. Teaching and Learning Forum. Retrieved from https://ctl.curtin.edu.au/events/conferences/tlf/tlf2011/refereed/shah.html 